\title{
Kajian Distribusi Spasial Dan Temporar Kadar BOD, TSS dan Oksigen Terlarut (DO) Air Sungai Batang Harau Kota Padang
}

\section{Study of Spatial and Temporal Distribution Levels of BOD, TSS and Dissolved Oxygen (DO) in Batang Harau River Padang City}

\author{
Burhan Muslim $^{\text {a }}$, Sejati ${ }^{\mathrm{b}}$, Awalia Gusti ${ }^{\mathrm{c}}$, Evino Sugriarta ${ }^{\mathrm{d}}$ \\ Jurusan Kesehatan Lingkungan Poltekkes Kemenkes Padang, Indonesia
}

\section{A B S T R A C T / A B S T R A K}

\begin{abstract}
Biological Oxygen Demand (BOD), Total Suspended Solid (TSS) and Dissolved Oxygen (DO) are indicators of water quality in water bodies. Non-polluted water has low BOD and TSS levels and high $D O$. Changes in these three parameters indicate a change in quality. This study aims to look at variations in the levels of BOD, TSS and DO spatially and temporarily in Batang Arau River, Padang City in 2018. The study was conducted by observing three stations, namely in the upstream, middle and downstream and in the morning and evening. The results showed that BOD and TSS levels tended to increase from upstream to downstream, while DO was the opposite. Temporar variation shows that $B O D$ and TSS levels are low in the morning and increase during the day and evening, while DO is the opposite.
\end{abstract}

Key word: Biological Oxygen Deman, Total Suspended Solid, Dissolved Oxygen

\begin{abstract}
Kebutuhan Oksigen Biologis (BOD), Total Suspended Solid (TSS) dan Dissolved Oxygen (DO) adalah indikator kualitas air dalam badan air. Air yang tidak tercemar memiliki kadar BOD dan TSS yang rendah serta DO yang tinggi. Perubahan dalam ketiga parameter ini menunjukkan perubahan kualitas. Penelitian ini bertujuan untuk melihat variasi kadar BOD, TSS dan DO secara spasial dan temporer di Sungai Batang Arau, Kota Padang pada tahun 2018. Jenis penelitian ini adalah deskriptif, sampel pemeriksaan sampel diambil dari air Sungai Batang Harau Kota Padang. Penelitian ini dilakukan dengan mengamati tiga stasiun, yaitu di hulu, tengah dan hilir dan pada pagi hari, dan malam. Hasil penelitian menunjukkan bahwa tingkat BOD dan TSS cenderung meningkat dari hulu ke hilir, sedangkan DO adalah sebaliknya. Variasi temporer menunjukkan bahwa tingkat BOD dan TSS rendah di pagi hari dan meningkat pada siang dan malam hari, sedangkan DO adalah sebaliknya.
\end{abstract}

Kata Kunci: BOD, TSS, DO

Alamat korespondensi email : burhanmuslim@poltekkes-pdg.ac.id

\section{PENDAHULUAN}

Batang Arau merupakan salah satu sungan yang mengalir melintasi Kota Padang. Sungai ini membentang dari Timur ke Barat yang bermuara ke kawasan Muaro Padang. Kawasan Muaro merupakan salah satu kawasan yang dikembangkan menjadi kawasan wisata Kota Padang mengingat kawasan ini merupakan kawasan kota lama yang banyak ditemukan bangunan tua.

Batang Arau merupakan salah satu sungai yang telah mengalami pencemaran di Kota Padang. Berdasarkan pemeriksaan yang dilakukan oleh Bapedalda Propinsi Sumatera Barat, beberapa parameter telah berada di atas baku mutu lingkungan. Parameter tersebut antara lain adalah Biological Oxygen Demand (BOD), Total Suspended Solid (TSS), sementara kandungan oksigen terlarut (Dissolved Oxygen) juga lebih rendah dari baku mutu lingkungan.

Bahan polutan yang mencemari air sungai Batang Arau berasal dari beberapa sumber, antara lain industri, rumah tangga, serta kegiatan pertanian dan peternakan. Beberapa Industri yang berkontribusi menyumbang polutan ke aliran Batang Arau antara lain adalah PT. Semen Padang. Pabrik Karet Famili Raya, dan beberapa rumah sakit, serta beberapa industri rumahan. Limbah 
Jurnal Kesehatan Lingkungan

Vol.10, No.2, Oktober 2020, pp. 45 - 51

ISSN 2615-188X(Online), ISSN 2089 - 0451(Print)

DOI: $10.47718 / \mathrm{jkl} . \mathrm{v} 10 \mathrm{i} 2.1161$

Journal homepage: https://ejurnal.poltekkes-manado.ac.id/index.php/jkl rumah tangga yang masuk ke aliran Batang Arau berasal dari perumahan pendudukan yang berada di sepanjang aliran sungai. Kegiatan pertanian dan peternakan yang ada di sepanjang aliran sungai juga berkontribusi menyumbang bahan polutan ke aliran sungai Batang Arau.

Penurunan kualitas air sungai Batang Arau patut menjadi perhatian semua pihak, karena sungai tersebut dipergunakan untuk banyak peruntukan oleh masyarakat. Sebagian masyarakat yang bermukim di sepanjang aliran sungai menggunakan air sungai Batang Arau sebagai sumber air bersih untuk berbagai keperluan seperti mandi, cuci dan kebersihan lainnya. Sebagian masyarakat menggunakan air sungai Batang Arau untuk perikanan. Pada bagian hilir, sungai ini melintasi tempat wisata Jembatan Siti Nurbaya dan Pelabuhan Muaro Padang.

Dilihat dari kemerataan, distribusi sumber polutan yang mencemari Batang Arau, tidak merata di sepanjang aliran sungai. Di bagian hulu sungai, sumber polutan relatif sedikit dan semakin ke hilir sumber polutan juga semakin banyak. Ditinjau dari segi waktu, maka jumlah polutan yang dibuang ke aliran sungai juga berubah-rubah. Beberapa industri membuang limbah pada waktu malam, sementara yang lain membuang pada waktu siang. Distribusi sumber polutan secara spasial dan temporal yang bervariasi akan berpengaruh terhadap fluktuasi kualitas air sungai Batang Arau secara spasial dan temporal.

Kebutuhan oksigen biologi (BOD) didefinisikan sebagai banyaknya oksigen yang diperlukan oleh organisme pada saat pemecahan bahan organik, pada kondisi aerobik. Pemecahan bahan organik diartikan bahwa bahan organik ini digunakan oleh organisme sebagai bahan makanan dan energinya diperoleh dari proses oksidasi. Parameter BOD, secara umum banyak dipakai untuk menentukan tingkat pencemaran air buangan. Penentuan BOD sangat penting untuk menelusuri aliran pencemaran dari hulu ke muara. Sesungguhnya penentuan BOD merupakan suatu prosedur bioassay yang menyangkut pengukuran banyaknya oksigen yang digunakan oleh organisme selama organisme tersebut menguraikan bahan organik yang ada dalam suatu perairan, pada kondisi yang harnpir sama dengan kondisi yang ada di alam. ${ }^{1}$

Oksigen dibutuhkan oleh semua jasad hidup untuk pernapasan, proses metabolisme atau pertukaran zat yang kemudian menghasilkan energi untuk pertumbuhan dan pembiakan. Disamping itu, oksigen juga dibutuhkan untuk oksidasi bahanbahan organik dan anorganik dalam proses aerobik.

Sumber utama oksigen dalam suatu perairan berasal sari suatu proses difusi dari udara bebas dan hasil fotosintesis organisme yang hidup dalam perairan tersebut. Kecepatan difusi oksigen dari udara, tergantung dari beberapa faktor, seperti kekeruhan air, suhu, salinitas, pergerakan massa air dan udara seperti arus, gelombang dan pasang surut. ${ }^{2}$

Kadar oksigen dalam air laut akan bertambah dengan semakin rendahnya suhu dan berkurang dengan semakin tingginya salinitas. Pada lapisan permukaan, kadar oksigen akan lebih tinggi, karena adanya proses difusi antara air dengan udara bebas serta adanya proses fotosintesis. Dengan bertambahnya kedalaman akan terjadi penurunan kadar oksigen terlarut, karena proses fotosintesis semakin berkurang dan kadar oksigen yang ada banyak digunakan untuk pernapasan dan oksidasi bahan-bahan organik dan anorganik. ${ }^{3}$

Keperluan organisme terhadap oksigen relatif bervariasi tergantung pada jenis, stadium dan aktifitasnya. Kebutuhan oksigen untuk ikan dalam keadaan diam relatif lebih sedikit apabila dibandingkan dengan ikan pada saat bergerak atau memijah. Jenis-jenis ikan tertentu yang dapat menggunakan oksigen dari udara bebas, memiliki daya tahan yang lebih terhadap perairan yang kekurangan oksigen terlarut. Kandungan oksigen terlarut (DO) minimum adalah 2 ppm dalam keadaan nornal dan tidak tercemar oleh senyawa beracun (toksik). Kandungan oksigen terlarut minimum ini sudah cukup mendukung kehidupan organisme. Idealnya, kandungan oksigen terlarut tidak boleh kurang dari 1,7 ppm selama waktu 8 jam dengan sedikitnya pada tingkat kejenuhan sebesar $70 \%$. KLH menetapkan bahwa kandungan oksigen terlarut adalah 5 ppm untuk kepentingan wisata bahari dan biota laut. ${ }^{4}$

Sebagaimana diketahui bahwa oksigen berperan sebagai pengoksidasi dan pereduksi bahan kimia beracun menjadi senyawa lain yang lebih sederhana dan tidak beracun. Disamping itu, oksigen juga sangat dibutuhkan oleh mikroorganisme untuk pernafasan. Organisme tertentu, seperti mikroorganisme, sangat berperan dalam menguraikan senyawa kimia beracun rnenjadi senyawa lain yang lebih sederhana dan tidak beracun. Karena peranannya yang penting ini, air buangan industri dan limbah sebelum dibuang ke lingkungan umum terlebih dahulu diperkaya kadar oksigennya. ${ }^{2}$

TSS (Total Suspended Solid) atau total padatan tersuspensi adalah padatan yang tersuspensi di dalam air berupa bahan-bahan organik dan inorganik yang dapat disaring dengan kertas millipore berpori-pori $0,45 \mu \mathrm{m}$. Materi yang 
Journal homepage: https://ejurnal.poltekkes-manado.ac.id/index.php/jkl tersuspensi mempunyai dampak buruk terhadap kualitas air karena mengurangi penetrasi matahari ke dalam badan air, kekeruhan air meningkat yang menyebabkan gangguan pertumbuhan bagi organisme produser. Pengukuran TSS berdasarkan pada berat kering partikel yang terperangkap oleh filter, biasanya dengan ukuran pori tertentu. Umumnya, filter yang digunakan memiliki ukuran pori $0.45 \mu \mathrm{m}^{5}$

TSS dari contoh air biasanya ditentukan dengan cara menuangkan air dengan volume tertentu, biasanya dalam ukuran liter, melalui sebuah filter dengan ukuran pori-pori tertentu. Sebelumnya, filter ini ditimbang dan kemudian beratnya akan dibandingkan dengan berat filter setelah dialirkan air setelah mengalami pengeringan. Berat filter tersebut akan bertambah disebabkan oleh terdapatnya partikel-partikel tersuspensi yang terperangkap dalam filter tersebut. Padatan yang tersuspensi ini dapat berupa bahanbahan organik dan inorganik. Satuan TSS adalah miligram per liter $(\mathrm{mg} / \mathrm{l})^{6}$

Kandungan TSS memiliki hubungan yang erat dengan kecerahan perairan. Keberadaan padatan tersuspensi tersebut akan menghalangi penetrasi cahaya yang masuk ke perairan sehingga hubungan antara TSS dan kecerahan akan menunjukkan hubungan yang berbanding terbalik. ${ }^{7}$

Nilai TSS umumnya semakin rendah ke arah laut. Hal ini disebabkan padatan tersuspensi tersebut disupply oleh daratan melalui aliran sungai (Helfinalis, 2005). Keberadaan padatan tersuspensi masih bisa berdampak positif apabila tidak melebihi toleransi sebaran suspensi baku mutu kualitas perairan yang ditetapkan oleh Kementrian Lingkungan Hidup, yaitu $70 \mathrm{mg} / \mathrm{l}^{8}$

Secara umum tujuan penelitian ini adalah diketahuinya distribusi spasial dan temporal kadar BOD, TSS dan DO air sungai Batang Arau Kota Padang tahun 2018

\section{METODE}

Penelitian ini merupakan penelitian survai dengan menggunakan analisis deskriptif. Penelitian dilakukan di sepanjang aliran sungai Batang Arau Kota Padang, sementara analisis kadar BOD, TSS dan DO dilakukan di Balai Laboratorium Kesehatan Daerah Sumatera Barat. Penelitian ini dilaksanakan dari bulan Juli sampai September 2018. Objek Penelitian adalah air sungai Batang Arau Kota Padang. Sampel air sungai diambil pada bagian hulu, pertengahan dan muara sungai, dengan waktu yang berbeda dan lokasi pengambilan yang terpisah pada tiap titik sampel. Lokasi pengambilan di bagian hulu dilakukan di Lubuk Paraku, lokasi pengambilan di bagian tengah dilakukan di jembatan Ujung Tanah Lubuk Begalung, dan lokasi pengambilan di bagian hilir adalah di Jembatan Siti Nurbaya Muaro Padang. Waktu pengambilan sampel dilakukan pagi, jam 05 sampai 07.00, siang dilakukan pada jam 12.00 sampai Jam 14.00, dan sore hari dilakukan jam 17.00 sampai 19.00.

Distribusi spasial, adalah gambaran sebaran menurut tempat (spasial) variasi kadar BOD, TSS dan DO yang ditunjukkan melalui tiga lokasi pengamatan yaitu di daerah hulu, tengah dan hilir sungai Batang Arau. Distribusi temporal, adalah gambaran sebaran menurut waktu (temporal) variasi kadar BOD, TSS, dan DO yang ditunjukkan melalui tiga dan empat waktu pengamatan, yaitu pagi, siang, sore dan malam hari.

Penentuan titik pengamatan/pengambilan sampel

a. Pengamatan untuk wilayah hulu sungai dilakukan di daerah Indarung

b. Pengamatan untuk wilayah pertengahan dilakukan di wilayah Sekitar Jembatan Ujung Tanah Lubuk Begalung Padang

c. Pengamatan untuk wilayah muara dilakukan di Pelabuhan Muaro Padang

Penentuan waktu pengamatan/pengambilan sampel

a. Pengambilan sampel pagi dilakukan pukul 05.00 sampai pukul 07.00 pada masing-masing titik pengamatan

b. Pengambilan sampel siang dilakukan pukul 12.00 sampai pukul 14.00 pada masing-masing titik

c. Pengambilan sampel sore/malam dilakukan pukul 17.00 sampai pukul 19.00 pada masingmasing titik

Pengolahan dan Analisis Data

1. Kajian distribusi spasial dilakukan dengan membandingkan hasil pengukuran parameter dari pada masing-masing titik pengamatan. Perbandingan dilakukan melalui perbandingan angka mutlak, perbandingan dengan baku mutu, dan perbandingan dengan menggunakan grafik.

2. Pengkajian distribusi temporal dilakukan dengan membandingkan hasil pengukuran parameter masing-masing waktu pengambilan. Perbandingan dilakukan dengan perbandingan angka mutlak, perbandingan dengan baku mutu, dan perbandingan dengan menggunakan grafik.

\section{HASIL}

1. Variasi kadar TSS, BOD dan DO pagi hari menurut lokasi pengambilan

Kadar BOD, TSS dan DO bervariasi 
Jurnal Kesehatan Lingkungan

Vol.10, No.2, Oktober 2020, pp. 45 - 51

ISSN 2615-188X(Online), ISSN 2089 - 0451(Print)

DOI: $10.47718 / \mathrm{jkl} . v 10 \mathrm{i} 2.1161$

Journal homepage: https://ejurnal.poltekkes-manado.ac.id/index.php/jkl

berdasarkan lokasi pengambilan sampel waktu

pagi hari. Variasi tersebut terlihat dari tabel 1 :

Tabel 1: Kadar BOD, TSS, dan DO Pada Pengambilan Pagi Hari di Lokasi Lubuk Paraku, Ujung Tanah, dan Muaro

\begin{tabular}{lcccc}
\hline \multicolumn{1}{c}{ Parameter } & Baku Mutu & Lb.Paraku & Uj.Tanah & Muaro \\
\hline 1. TSS & 50 & 2,0 & 52 & 54 \\
2. BOD-5 & 3 & 1,2 & 3,5 & 4,3 \\
3. DO & 4 & 8,3 & 2,01 & 1,01 \\
\hline
\end{tabular}

Hasil pengukuran pagi hari terlihat di daerah Lubuk Paraku TSS masih rendah, BOD-5 masih rendah, dan DO masih tinggi. Keadaan ini memperlihatkan kualitas air masih tinggi. Hasil pengukuran di Ujung Tanah terlihat TSS jauh meningkat dari 2 menjadi 52, BOD-5 sudah naik dari 1,2 menjadi 3,5 dan DO sudah turun dari 8,3 menjadi 2,01. Hal ini menunjukkan telah ada pencemar yang masuk ke aliran air antara lubuk Paraku dan Ujung Tanah. Pengukuran di Muaro ternyata lebih rendah dari Ujung Tanah, TSS naik menjadi 54, BOD-5 naik menjadi 4,3 dan DO semakin turun dari 2,01 menjadi 1,01.

Hasil pengukuran pagi ini, terlihat bahwa telah ada pencemar yang memasuki aliran sungai Batang Arau di antara daerah Lubuk Paraku dengan Ujung Tanah serta antara Ujung Tanah dengan Muaro. Keadaan ini jelas terlihat dengan makin meningkatnya kadar TSS dan BOD-5 serta semakin turunnya kadar DO.

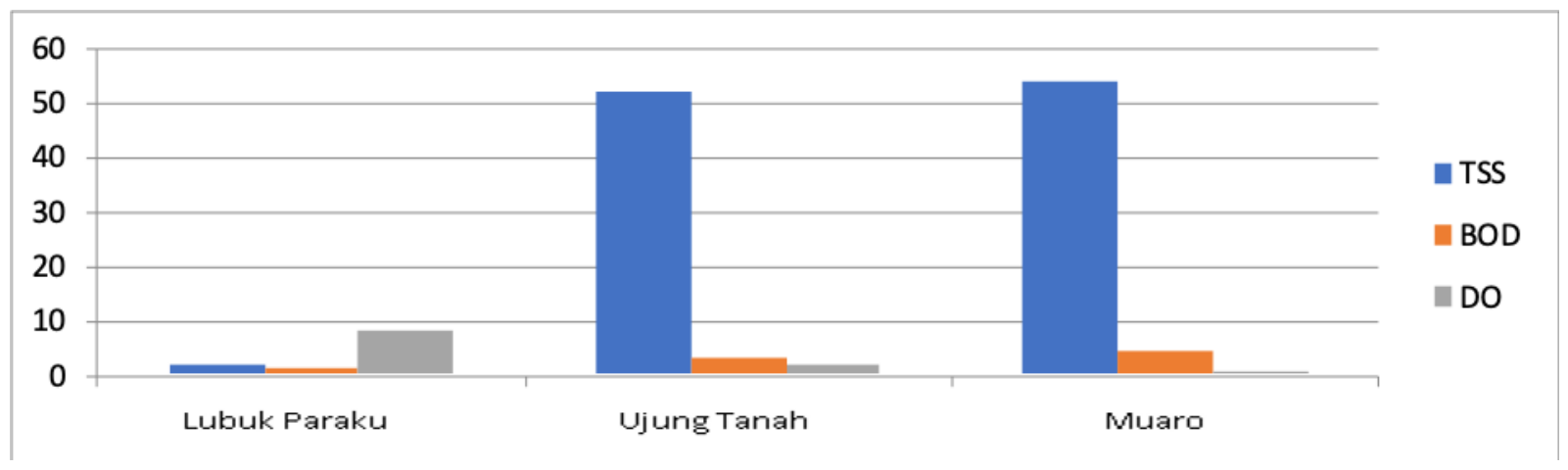

Gambar 1. Grafik Variasi Kadar TSS, BOD, dan DO Pagi Hari pada Lokasi Pengambilan Lubuk Paraku, Ujung Tanah, dan Muaro

2. Variasi Kadar TSS, BOD, dan TSS Siang Hari menurut lokasi pengambilan

Kadar BOD, TSS dan DO juga bervariasi

berdasarkan lokasi pengambilan pada siang hari. Variasi tersebut dapat dilihat pada Tabel 2

Tabel 2: Kadar BOD, TSS, dan DO Pada Pengambilan Siang Hari di Lubuk Paraku, Ujung Tanah, dan Muaro

\begin{tabular}{lcccc}
\hline \multicolumn{1}{c}{ Parameter } & Baku Mutu & Lb.Paraku & Uj.Tanah & Muaro \\
\hline 1. TSS & 50 & 2,3 & 43 & 57 \\
2. BOD-5 & 3 & 1,2 & 3,2 & 4,1 \\
3. DO & 4 & 8,3 & 2,03 & 1,32 \\
\hline
\end{tabular}

Hasil pengukuran sampel siang hari terlihat di daerah Lubuk Paraku TSS masih rendah, BOD-5 masih rendah, dan DO masih tinggi. Keadaan ini memperlihatkan kwalitas air masih tinggi, tidak jauh berbeda dengan keadaan pagi hari. Hasil pengukuran di Ujung Tanah terlihat TSS meningkat dari 2,3 menjadi 43, BOD-5 sudah naik dari 1,2 menjadi 3,2 dan DO sudah turun dari 8,3 menjadi 2,03. Bila dibandingkan keadaan pencemaran dari 
Jurnal Kesehatan Lingkungan

Vol.10, No.2, Oktober 2020, pp. 45 - 51

ISSN 2615-188X(Online), ISSN 2089 - 0451(Print)

DOI: $10.47718 / \mathrm{jkl} . v 10 \mathrm{i} 2.1161$

Journal homepage: https://ejurnal.poltekkes-manado.ac.id/index.php/jkl pengambilan sampel pagi hari dengan siang hari di lokasi Ujung Tanah, ternyata ada penurunan. Hal ini mungkin disebabkan adanya waktu istirahat siang yang menyebabkan terhentinya pembuangan limbah ke sungai. Pengukuran di Muaro ternyata lebih jelek dari Ujung Tanah, dapat dilihat dari pengukuran TSS dari 43 naik menjadi 57, BOD-5 dari 3,2 menjadi 4,1 dan DO turun dari 2,03 menjadi 1,32 .

Hasil pengukuran siang hari, terlihat bahwa telah ada pencemar yang memasuki aliran sungai Batang Arau di antara daerah

Lubuk Paraku dengan Ujung Tanah serta antara Ujung Tanah dengan Muaro yang terjadi pada siang hari. Keadaan ini jelas terlihat dengan makin meningkatnya kadar TSS dan BOD-5 serta semakin turunnya kadar DO. Pada daerah Muaro terjadi peningkatan kadar TSS hasil pengukuran siang hari dibandingkan dengan hasil pengukuran pagi hari. Sedangkan hasil pengukuran kadar BOD-5 terjadi penurunan dibandingkan antara pengukuran siang hari dengan pengukuran pagi hari. Hasil pengukuran DO siang hari ternyata lebih baik dibandingkan antara pengukuran siang hari dengan pagi hari.

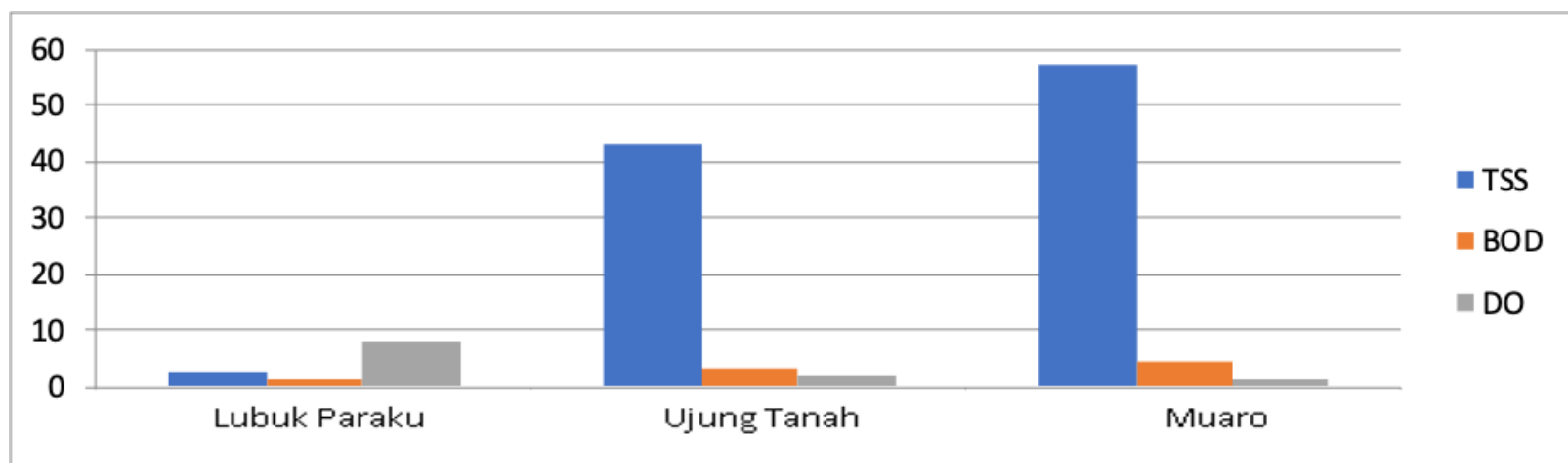

Gambar 2. Grafik Variasi Kadar TSS, BOD, dan DO Siang Hari pada Lokasi Pengambilan Lubuk Paraku, Ujung Tanah, dan Muaro

3. Variasi kadar BOD, TSS dan DO pada

Pengambilan Sampel Sore Hari menurut lokasi

Pengambilan sampel yang dilakukan pada sore hari pada tiga lokasi juga menunjukkan variasi kadar BOD, TSS dan DO. Variasi tersebut dapat dilihat pada Tabel 3

Tabel 3: Kadar BOD, TSS, dan DO Pada Pengambilan Sore/Malam Hari di Lubuk Paraku, Ujung Tanah dan Muaro

\begin{tabular}{lcccc}
\hline \multicolumn{1}{c}{ Parameter } & Baku Mutu & Lb.Paraku & Uj.Tanah & Muaro \\
\hline 1. TSS & 50 & 2,5 & 45 & 54 \\
2. BOD-5 & 3 & 1,4 & 3,4 & 4,7 \\
3. DO & 4 & 7,9 & 2,02 & 1,00
\end{tabular}

Hasil pengukuran TSS dan BOD-5 di Lubuk Paraku sore/malam hari, terjadi sedikit peningkatan dibandingkan dengan pengukuran pada pagi dan siang hari. Hal ini mungkin oleh karena telah ada aktivitas masyarakat yang bermukim di sekitar daerah Lubuk paraku dan mencemari sungai disitu. Hasil pengukuran parameter pencemar di Ujung Tanah pada sore/malam hari, terdapat sedikit peningkatan dibandingkan dengan pengukuran yang dilakukan pada siang hari. Tetapi bila dibandingkan pengukuran parameter pencemar ini (TSS dan BOD-5) antara Ujung Tanah dengan Lubuk
Paraku, ternyata banyak peningkatan. Sedangkan DO terjadi penurunan, yang menunjukkan banyaknya penggunaan oksigen terlarut oleh pencemar.

Dilihat dari perubahan lokasi, kadar pencemar (TSS dan BOD-5), mulai dari Lubuk Paraku, Ujung Tanah dan Muaro, terjadi peningkatan, baik pada pengambilan sampel pagi hari, siang hari ataupun sore/malam hari.

Jika ditinjau dari masing-masing lokasi, pada Lubuk Paraku kadar pencemar TSS dan BOD-5 masih belum melampaui baku mutu, hasil pengambilan sampel pagi, siang ataupun 
Journal homepage: https://ejurnal.poltekkes-manado.ac.id/index.php/jkl sore/malam hari. Demikianpun DO masih jauh di atas baku mutu yang ditetapkan.

Hasil pengukuran sampel pada lokasi Ujung Tanah, TSS melampaui baku mutu pada pengukuran pagi hari, sedangkan pada siang dan sore hari tidak melampaui baku mutu. Hasil pengukuran BOD-5 telah melampaui baku mutu pada ketiga waktu pengambilan. Pengukuran DO ternyata kurang dari batas baku mutu yang

\section{PEMBAHASAN}

1. Variasi kadar TSS, BOD dan DO pagi hari menurut lokasi pengambilan

Hasil pengukuran pagi hari terlihat di daerah Lubuk Paraku TSS masih rendah, BOD-5 masih rendah, dan DO masih tinggi. Keadaan ini memperlihatkan kualitas air masih tinggi. Hasil pengukuran di Ujung Tanah terlihat TSS jauh meningkat dari 2 menjadi 52, BOD-5 sudah naik dari 1,2 menjadi 3,5 dan DO sudah turun dari 8,3 menjadi 2,01. Hal ini menunjukkan telah ada pencemar yang masuk ke aliran air antara lubuk Paraku dan Ujung Tanah. Pengukuran di Muaro ternyata lebih rendah dari Ujung Tanah, TSS naik menjadi 54, BOD-5 naik menjadi 4,3 dan DO semakin turun dari 2,01 menjadi 1,01.

Hasil pengukuran pagi ini, terlihat bahwa telah ada pencemar yang memasuki aliran sungai Batang Arau di antara daerah Lubuk Paraku dengan Ujung Tanah serta antara Ujung Tanah dengan Muaro. Keadaan ini jelas terlihat dengan makin meningkatnya kadar TSS dan BOD-5 serta semakin turunnya kadar DO.

2. Variasi Kadar TSS, BOD, dan TSS Siang Hari menurut lokasi pengambilan

Kadar BOD, TSS dan DO juga bervariasi berdasarkan lokasi pengambilan pada siang hari. Variasi kadar BOD, TSS dan DO berdasarkan lokasi pengambilan pada siang hari. Variasi tersebut dapat dilihat berdasarkan hasil pengukuran sampel siang hari terlihat di daerah Lubuk Paraku TSS masih rendah, BOD-5 masih rendah, dan DO masih tinggi. Keadaan ini memperlihatkan kwalitas air masih tinggi, tidak jauh berbeda dengan keadaan pagi hari. Hasil pengukuran di Ujung Tanah terlihat TSS meningkat dari 2,3 menjadi 43, BOD-5 sudah naik dari 1,2 menjadi 3,2 dan DO sudah turun dari 8,3 menjadi 2,03. Bila dibandingkan keadaan pencemaran dari pengambilan sampel pagi hari dengan siang hari di lokasi Ujung Tanah, ternyata ada penurunan. Hal ini mungkin disebabkan adanya waktu istirahat siang yang menyebabkan terhentinya pembuangan limbah ke ditetapkan pada ketiga waktu pengambilan, tetapi masih di atas batas minimum DO.

Hasil pengukuran sampel pada lokasi Muara, ternyata kadar TSS dan BOD-5 telah melampaui baku mutu pada waktu pengambilan pagi, siang dan sore/malam hari. Hasil pengukuran DO jauh di bawah baku mutu yang ditetapkan, dan di bawah batas minimum DO.

sungai. Pengukuran di Muaro ternyata lebih jelek dari Ujung Tanah, dapat dilihat dari pengukuran TSS dari 43 naik menjadi 57, BOD-5 dari 3,2 menjadi 4,1 dan DO turun dari 2,03 menjadi 1,32 .

Hasil pengukuran siang hari, terlihat bahwa telah ada pencemar yang memasuki aliran sungai Batang Arau di antara daerah Lubuk Paraku dengan Ujung Tanah serta antara Ujung Tanah dengan Muaro yang terjadi pada siang hari. Keadaan ini jelas terlihat dengan makin meningkatnya kadar TSS dan BOD-5 serta semakin turunnya kadar DO. Pada daerah Muaro terjadi peningkatan kadar TSS hasil pengukuran siang hari dibandingkan dengan hasil pengukuran pagi hari. Sedangkan hasil pengukuran kadar BOD-5 terjadi penurunan dibandingkan antara pengukuran siang hari dengan pengukuran pagi hari. Hasil pengukuran DO siang hari ternyata lebih baik dibandingkan antara pengukuran siang hari dengan pagi hari.

3. Variasi kadar BOD, TSS dan DO pada Pengambilan Sampel Sore Hari menurut lokasi Pengambilan sampel yang dilakukan pada sore hari pada tiga lokasi juga menunjukkan variasi kadar BOD, TSS dan DO. Variasi hasil pengukuran TSS dan BOD-5 di Lubuk Paraku sore/malam hari, terjadi sedikit peningkatan dibandingkan dengan pengukuran pada pagi dan siang hari. Hal ini mungkin oleh karena telah ada aktivitas masyarakat yang bermukim di sekitar daerah Lubuk paraku dan mencemari sungai disitu. Hasil pengukuran parameter pencemar di Ujung Tanah pada sore/malam hari, terdapat sedikit peningkatan dibandingkan dengan pengukuran yang dilakukan pada siang hari. Tetapi bila dibandingkan pengukuran parameter pencemar ini (TSS dan BOD-5) antara Ujung Tanah dengan Lubuk Paraku, ternyata banyak peningkatan. Sedangkan DO terjadi penurunan, yang menunjukkan banyaknya penggunaan oksigen terlarut oleh pencemar.

Dilihat dari perubahan lokasi, kadar pencemar (TSS dan BOD-5), mulai dari Lubuk Paraku, Ujung Tanah dan Muaro, terjadi 

peningkatan, baik pada pengambilan sampel pagi hari, siang hari ataupun sore/malam hari.

Jika ditinjau dari masing-masing lokasi, pada Lubuk Paraku kadar pencemar TSS dan BOD-5 masih belum melampaui baku mutu, hasil pengambilan sampel pagi, siang ataupun sore/malam hari. Demikianpun DO masih jauh di atas baku mutu yang ditetapkan.

Hasil pengukuran sampel pada lokasi Ujung Tanah, TSS melampaui baku mutu pada pengukuran pagi hari, sedangkan pada siang dan sore hari tidak melampaui baku mutu. Hasil pengukuran BOD-5 telah melampaui baku mutu pada ketiga waktu pengambilan. Pengukuran DO ternyata kurang dari batas baku mutu yang ditetapkan pada ketiga waktu pengambilan, tetapi masih di atas batas minimum DO.

Hasil pengukuran sampel pada lokasi Muara, ternyata kadar TSS dan BOD-5 telah melampaui baku mutu pada waktu pengambilan pagi, siang dan sore/malam hari. Hasil pengukuran DO jauh di bawah baku mutu yang ditetapkan, dan di bawah batas minimum DO.

\section{KESIMPULAN}

1. Kadar BOD dan TSS cenderung meningkat dari arah hulu ke hilir, sementara kadar DO venderung menurun dari arah hulu ke hilir Sungai Batang Harau Kota Padang

2. Kadar BOD dsn TSS cenderung meningkat dari pagi sampai sore hari pada semua titik pengamatan Sungai Batang Harau Kota Padang

\section{DAFTAR PUSTAKA}

1. Young, I. G., Lipták, B. G., \& Tatera, J. F. (2003). Biological oxygen demand, chemical oxygen demand, and total oxygen demand. In Instrument Engineers' Handbook: Process Measurement and Analysis, Fourth Edition

2. Burhan Muslim. (2016). Buku Ajar Ekologi (I). Politeknik Kesehatan Kemenkes Padang.

3. Burhan Muslim. (2017). Pedoman Praktikum Ekologi (II). Politeknik Kesehatan Kemenkes Padang.

4. Salmin. (2005a). Oksigen Terlarut (DO) Dan Kebutuhan Oksigen Biologi (BOD) Sebagai Salah Satu Indikator Untuk Menentukan. Oseana. https:// doi.org/10.1080/ 00958970500395898

5. Salmin. (2005b). Oksigen terlarut (DO) Dan kebutuhan oksigen biologi (BOD) sebagai salah satu indikator untuk menentukan kualitas perairan. Oseana

6. Tuttle-Raycraft, S., Morris, T. J., \& Ackerman, J. D. (2017). Suspended solid concentration reduces feeding in freshwater mussels. Science of the Total Environment. https://doi.org/10.1016/j.scitotenv.2017.04.127

7. Fondriest Environmental, I. (2015). Turbidity, Total Suspended Solids \& Water Clarity Environmental Measurement Systems. Http://Www.Fondriest.Com. https://doi.org/ 10.1016/j.ajog

8. Sholihah, I., Jaelani, L. M., \& Tarigan, S. (2016). Analisis Sebaran Padatan Tersuspensi dan Transparansi Perairan Menggunakan Landsat 8 (Studi Kasus: Perairan Bntan, Kepulauan Riau). Jurnal Teknik ITS. https://doi.org/10.1016/S1470-2045(03)00984-7

9. Helfinalis. (2005). Suspensi dan endapan sedimen di perairan Laut Jawa. Makara, Sains. https://doi.org/10.1073/pnas.0304262101 